\title{
Field relations and petrology of the Trafalgar Plutonic Suite and comparisons with other Devonian granitoid plutons in the Meguma terrane, Nova Scotia, Canada
}

\author{
Raya C. Puchalski ${ }^{1}$, Sandra M. BARR ${ }^{1^{*}}$, ANd Chris E. White ${ }^{2}$ \\ 1. Department of Earth and Environmental Science, Acadia University, Wolfville, Nova Scotia B4P 2R6, Canada \\ † Current address: 500 Toledo St., Thunder Bay Ontario P7A 8A6 \\ 2. Geological Survey, Nova Scotia Department of Energy and Mines, Halifax, Nova Scotia B3J 2T9, Canada \\ ${ }^{*}$ Corresponding author $<$ sandra.barr@acadiau.ca $>$
}

Date received: 26 November 2019 Date accepted: 15 March 2020

\begin{abstract}
The Trafalgar Plutonic Suite intruded metasedimentary rocks of the Goldenville and Halifax groups in the northeastern part of the Meguma terrane of southern Nova Scotia at about $374 \mathrm{Ma}$, based on previously published $\mathrm{U}-\mathrm{Pb}$ and ${ }^{40} \mathrm{Ar} /{ }^{39} \mathrm{Ar}$ mineral ages. Using field and petrographic observations, the suite is divided into 20 different plutons on the combined basis of variations in grain size (fine, medium, or coarse), texture (equigranular or porphyritic) and modal mineralogy (quartz diorite/tonalite, granodiorite, monzogranite, and syenogranite). The granodiorite, monzogranite, and syenogranite plutons are relatively uniform in composition with little variation in mineralogy or chemistry within each pluton or between plutons of the same lithology. In contrast the quartz diorite/tonalite plutons show mineralogical and chemical variation, both within and between plutons. The granodiorite, monzogranite, and syenogranite plutons closely resemble other peraluminous granitoid plutons characteristic of the Meguma terrane. The quartz diorite/tonalite plutons are varied but chemically resemble minor Devonian mafic intrusions elsewhere in the Meguma terrane. Like other plutons of the Meguma terrane, the Trafalgar Plutonic Suite has chemical characteristics of volcanic-arc to syn-collisional granitoid rocks and likely has experienced extensive contamination by metasedimentary material as documented by previous studies of plutons in the Meguma terrane. The minor quartz diorite/tonalite plutons are additional examples of the mafic rocks that have been proposed in tectonic models of the Meguma terrane to have facilitated melting of the lower crust to generate granodioritic parent magmas, followed by crystal fractionation and extensive contamination by metasedimentary material.
\end{abstract}

\section{RÉSUMÉ}

La suite plutonique de Trafalgar s’est mise en place dans les roches métasédimentaires des groupes de Goldenville et Halifax dans la partie nord-est de la zone de Meguma au sud de la Nouvelle-Écosse à environ $374 \mathrm{Ma}$, d’après des âges $\mathrm{U}-\mathrm{Pb}$ et ${ }^{40} \mathrm{Ar}{ }^{39} \mathrm{Ar}$ déjà publiés. À partir d'observations sur le terrain et pétrographiques, la suite se divise en 20 plutons, basé sur un ensemble de caractéristiques telles que la variation granulométrique (fin, moyen ou grossier), la texture des roches (équidimensionnel ou porphyritique) et la proportion minéralogique (diorite quartzifère/tonalite, granodiorite, monzogranite et syénogranite). La composition des plutons constitués de granodiorite, de monzogranite et de syénogranite est relativement uniforme avec peu de variation minéralogique ou chimique au sein de chacun des plutons ou d'un pluton à un autre de lithologie semblable. En revanche, les plutons formés de diorite quartzifère/tonalite présentent des variations minéralogiques et chimiques à l'intérieur du même pluton et à travers la suite plutonique. Les plutons constitués de granodiorite, de monzogranite et de syénogranite ressemblent étroitement aux autres granitoïdes peralumineux de la zone de Meguma. Les plutons de diorite quartzifère/tonalite sont variables mais chimiquement comparables aux intrusions mafiques dévoniens retrouvés ailleurs dans la zone de Meguma. Comme plusieurs autres plutons de la zone de Meguma, la suite plutonique de Trafalgar possède des caractéristiques chimiques semblables aux granitoïdes de type arc volcanique à syncollisionnel et ayant sans doute subi une contamination significative des roches métasédimentaires, tels que documenté dans des études précédentes sur les plutons de la zone de Meguma. Les moins vastes plutons formés de diorite quartzifère/tonalite constituent des exemples supplémentaires de roches mafiques qui furent présentées dans des modèles tectoniques de la zone de Meguma comme ayant contribuées à la fusion de la croute inférieure et ainsi générer un magma parent granodioritique, suivi d'une cristallisation fractionnée combinée à une contamination importante provenant des roches métasédimentaires.

[Traduit par la redaction] 


\section{INTRODUCTION}

The Trafalgar Plutonic Suite (White et al. 2009a, b; White and Scallion 2011) is an assemblage of granitoid plutons in the Trafalgar area near the northern margin of the Meguma terrane in north-central Nova Scotia (Fig. 1). Fletcher (1887) referred to these plutons as the "Trafalgar Granite", and on early geological maps of the area (Faribault 1897; Fletcher and Faribault 1901), they were shown intruded into metasedimentary rocks of the "gold-bearing series" (now known as the Goldenville and Halifax groups; e.g., White 2010). Giles and Chatterjee (1986) introduced the term "Liscomb Complex" for the granitoid and surrounding rocks in the Trafalgar area, based on their interpretation that some of these rocks are gneiss which they considered to represent basement to the Meguma terrane. This interpretation was also made by Clarke et al. (1993), and the geological map of the Trafalgar area by Giles et al. (2008) showed several different units of mafic to felsic gneiss as well as granite plutons. Dostal et al. (2006) interpreted the "Liscomb Complex" to be a metamorphic core complex or domal uplift of high-grade metasedimentary and metavolcanic rocks.

In contrast, based on their mapping and petrological studies in the western part of the Trafalgar area, White et al. (2009a, b), Scallion (2010), Scallion et al. (2011), and White and Scallion (2011) reinterpreted the "gneissic rocks" of Giles and Chatterjee (1986) and subsequent workers as foliated granitoid rocks, contact metamorphosed metasedimentary rocks, and/or contaminated plutonic rocks. They assigned the metasedimentary rocks to the Goldenville and Halifax groups, and the varied plutonic rocks to the Trafalgar Plutonic Suite. Owen et al. (2010) agreed with some of these revised interpretations concerning the nature of the gneissic rocks but continued to support in part the earlier interpretations of Dostal et al. (2006), Giles and Chatterjee (1986), and Giles et al. (2008) that some rocks in the area may be basement gneiss.

To provide better understanding of the characteristics of plutons in the Trafalgar suite of White and Scallion (2011) and their relationship to better known granitoid plutons elsewhere in the Meguma terrane, Puchalski (2012) documented their field relations, petrography, mineral chemistry and whole-rock geochemistry. Her work was based on new mapping and sampling in the eastern part of the suite, as well as a compilation of previous published and unpublished data from the entire suite.

The purpose of this paper is to provide a geological overview of the Trafalgar Plutonic Suite and its host rocks, and to demonstrate that the plutons of the suite are like other plutonic rocks of similar age throughout the Meguma terrane.

\section{GEOLOGIC SETTING}

\section{Meguma terrane}

The Meguma terrane is the easternmost accreted terrane of the Appalachian orogen and is dominated by meta-

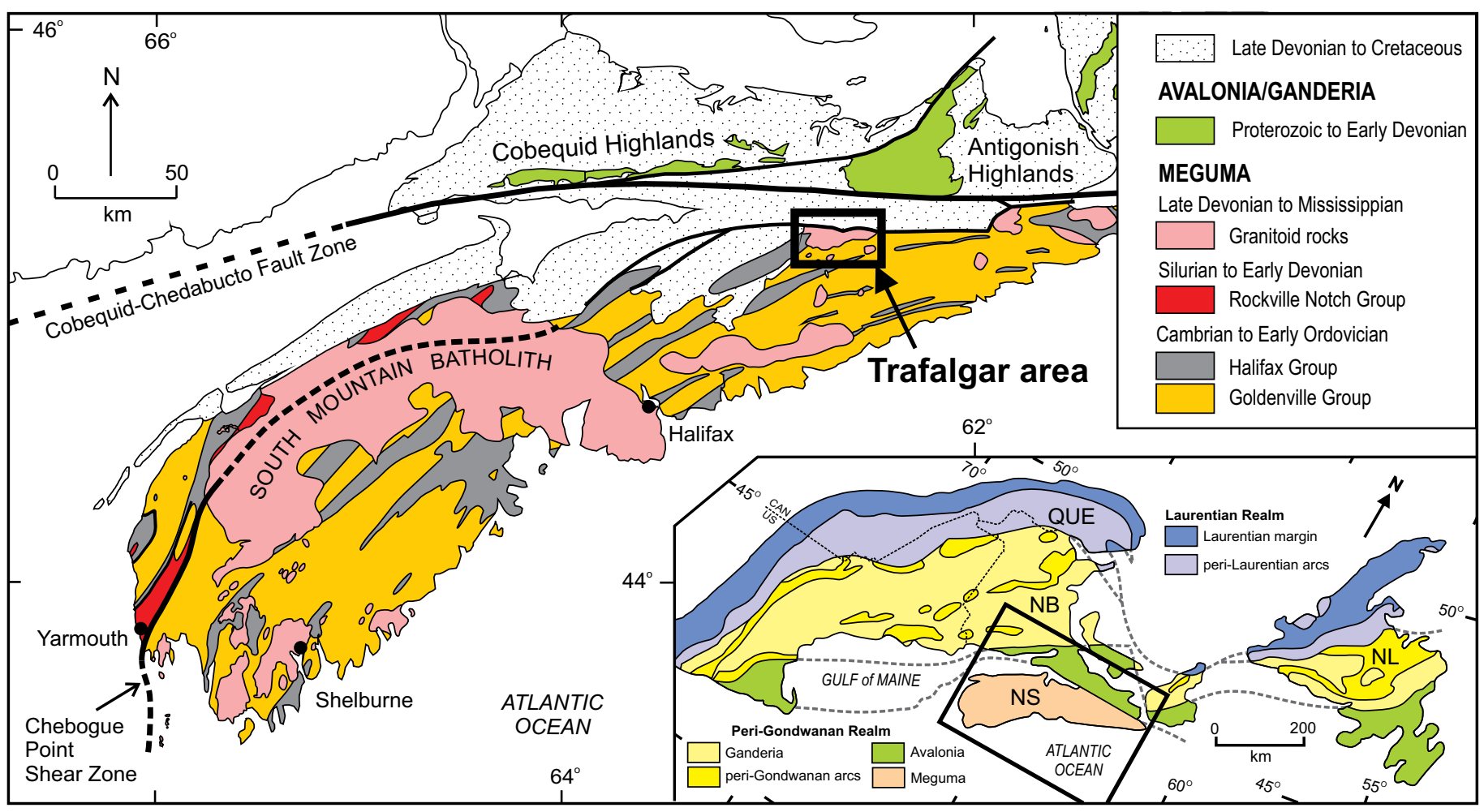

Figure 1. Simplified geological map of the Meguma terrane after White and Barr (2012) showing the location of the Trafalgar area. Inset map shows the position of the Meguma terrane in the northern Appalachian orogen after Hibbard et al. (2006). 
sedimentary rocks of the Goldenville and Halifax groups (Fig. 1). The Goldenville Group is the most extensive unit in the Meguma terrane and is primarily composed of thick layers of metasandstone separated by thinner layers of metasiltstone (White 2010). The group has been subdivided into several formations; in the Trafalgar area they include the Taylors Head and Beaverbank formations (Fig. 2). The overlying Halifax Group is composed of slate and metasiltstone with thin beds of metasandstone. It also has been subdivided into formations, including the Cunard and Glen Brook formations in the Trafalgar area (Fig. 2).

The Goldenville and Halifax groups were regionally deformed and metamorphosed to greenschist and locally amphibolite facies at ca. $395 \mathrm{Ma}$ during the Neoacadian orogeny (van Staal et al.2009; White and Barr 2012), an event generally attributed to the collision of the Meguma terrane and a part of Avalonia far east of the part of Avalonia with which the terrane is now juxtaposed along the Cobequid-Chedabucto Fault Zone (Murphy et al. 2011; Waldron et al. 2015; Archibald et al. 2018).

Numerous granitic plutons, including the South Mountain Batholith (Fig. 1), intruded the Meguma terrane at about 375-372 Ma. These mainly peraluminous plutons were strongly contaminated by abundant xenoliths and country rock assimilation, although the amount of contamination varies within individual plutons (e.g., MacLean et al. 2003; Clarke 2007; Erdmann et al. 2007, 2009; MacDonald and Clarke 2017). The granitic bodies were emplaced at moderate to shallow depths and were rapidly exhumed, forming narrow contact metamorphic aureoles surrounding the individual plutons (Mahoney 1996; Dostal et al. 2006; Jamieson et al. 2012). After exhumation, both Meguma and Avalonia were overlain by latest Devonian and Carboniferous sedimentary rocks of the Horton and Windsor groups and overlying units (e.g., Murphy et al. 2011; Archibald et al. 2018).

\section{Trafalgar Plutonic Suite}

The plutons of the Trafalgar suite intruded mainly metasedimentary rocks of the Taylors Head and overlying Beaverbank formations of the Goldenville Group (White and Scallion 2011). The Taylors Head Formation consists mainly of thickly bedded ( $1 \mathrm{~m}$ to several metres) metasandstone interlayered with thin metasiltstone beds generally less than $0.5 \mathrm{~m}$ thick. Calc-silicate lenses 1 to $20 \mathrm{~cm}$ thick are abundant. Toward the northeastern part of the map area, the Taylors Head Formation becomes progressively more mylonitic. In these areas, micas show preferred crystallographic orientation, go into optical extinction simultaneously, and display S- and C-fabric related to shearing. Post-tectonic staurolite grains in the more pelitic beds are poikiloblastic and include grains of micas which are oriented parallel to the S- and C- fabric, indicating that they overgrew the existing fabric and were the last minerals to form. The staurolite was likely formed during contact metamorphism caused by adjacent plutons, as described below.
The thin $(100-300 \mathrm{~m})$ Beaverbank Formation is in sharp contact with the underlying Taylors Head Formation and with the overlying Cunard Formation (White and Scallion 2011). It is composed of grey laminated metasiltstone, metasandstone, and coticules. The coticules are a distinguishing characteristic of the formation, related to its high Mn content. They form pink, locally ptygmatically folded, Mn-rich beds up to $10 \mathrm{~cm}$ thick.

The overlying Cunard and Glen Brook formations of the Halifax Group are preserved in synclines in the northern, central, and southeastern parts of the map area (Fig. 2). The Cunard Formation is typically black slate with interlayered metasiltstone and fine-grained metasandstone in sharp conformable contact the underlying manganiferous Beaverbank Formation. Weathered surfaces in the slate are typically rusty due to the weathering of the pyrite, arsenopryite, and other sulphide minerals. In some areas these pelitic rocks have been contact metamorphosed to form andalusite-bearing slate. Chiastolitic andalusite forms randomly oriented, elongate crystals up to $2 \mathrm{~cm}$ in length, that overgrew the foliation defined by micas, demonstrating that contact metamorphism post-dated regional metamorphism in the Trafalgar area. The overlying Glen Brook Formation is composed of grey metasiltstone and slate in the lower part and grey metasandstone in the upper part, in which trace fossils such as burrows and grazing trails are abundant. As documented by White et al. (2009b), the regional metamorphic grade in the Trafalgar area is generally in the greenschist facies (chlorite and biotite zones). Contact metamorphism overprinted earlier greenschist facies regional metamorphism in the vicinity of at least some plutons of the Trafalgar Plutonic Suite. The most well investigated contact metamorphic aureole in the map area is that surrounding the western lobe of the Twin Lakes pluton in pelitic rocks of the Cunard Formation as described by White et al. (2009b). Based on the documented mineral assemblages, White et al. (2009b) proposed an approximate maximum pressure and temperature $\sim 2.5 \mathrm{kbar}$ and $\sim 675^{\circ} \mathrm{C}$ in the contact metamorphic aureole. Overall, the metamorphic mineral assemblages suggest that plutons of the Trafalgar suite were emplaced at $\sim 8-8.5 \mathrm{~km}$ depth. Based on distribution of map units and structural data, a north-south cross-section of the map area illustrates that folds are inclined to slightly overturned and mainly verge to the south, cut by plutons of the Trafalgar Plutonic Suite (Fig. 2 inset).

Faults in the map area are inferred mainly based on offsets of magnetic anomalies (King 1997a, b, c, 2005). They typically strike northwest and the largest offsets are approximately $1 \mathrm{~km}$ (Fig. 2). The West River St. Marys Fault marks the contact between the older units and the Carboniferous Horton Group (Fig. 2). The West River St. Marys Fault has dextral motion, and splays into two separate faults west of the map area (Murphy et al. 2011; Archibald et al. 2018).

A zone of mylonite affecting both the metasedimentary rocks and granitoid plutons occurs in the northeastern part of the map area, including the Taylors Head Formation, Hattie Lake pluton and to a lesser extent, the Long John Lake 


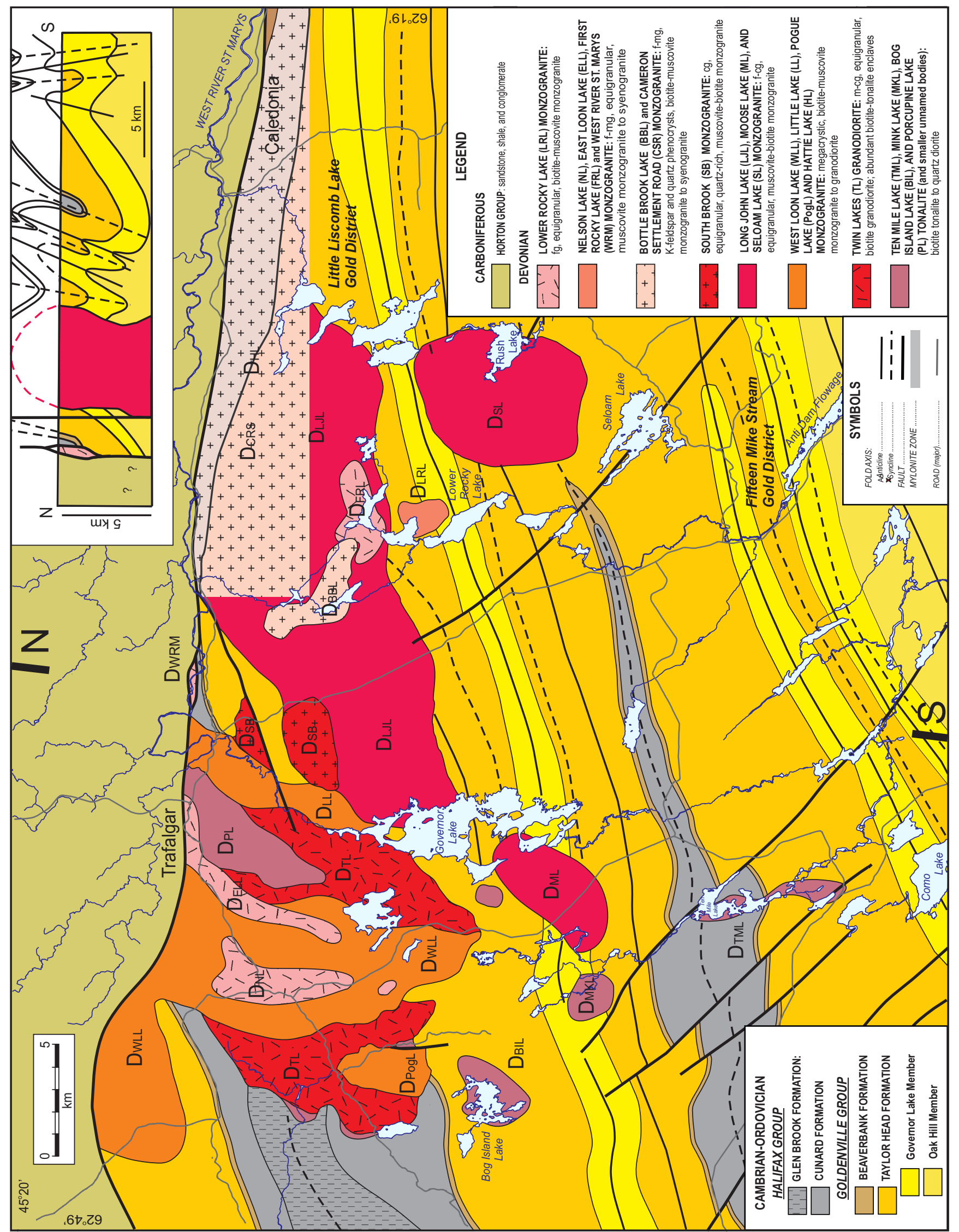

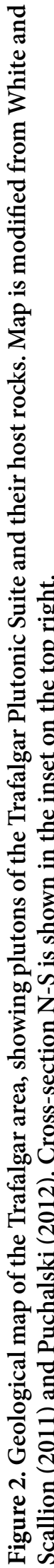


pluton (Fig. 2). The mylonite appears to be truncated on the northwest by the West River St. Marys Fault. It extends and widens to the east beyond the map area and includes the mylonitic Kelly Brook pluton of Archibald et al. (2018). The average mylonitic foliation strikes $\sim 270^{\circ}$ and dips $\sim 60^{\circ}$ with mineral lineations which have a trend and plunge of about $270 / 10^{\circ}$. Based on feldspar porphyroclasts in oriented thin sections from the Hattie Lake pluton, motion in the mylonite zone was dextral.

\section{DATABASE FOR THE TRAFALGAR PLUTONIC SUITE}

For the study of Puchalski (2012), plutons in the eastern part of the Trafalgar area were mapped and sampled which resulted in a modified distribution of plutonic units in the area compared to the map of White and Scallion (2011), as shown in Figure 2. From that work, 97 samples were collected for petrological study, including slabbing and staining for K-feldspar to facilitate modal analysis following the method of Hutchinson (1974). Sixty-eight of these samples were examined in thin section, and whole-rock chemical analyses were obtained for 25 samples. Analytical methods and data are documented in Puchalski (2012).

In addition, archived plutonic samples and thin sections available in collections at the Nova Scotia Department of Natural Resources were examined from throughout the Trafalgar area, including 28 samples from the work of Ford (1993), 260 samples from the work of Giles and Chatterjee (1986), and 147 samples from Scallion (2010). Sample locations and descriptions are in Puchalski (2012). Mineral analyses by electron microprobe from approximately 40 samples were also part of the archive, mainly unpublished data by A.K. Chatterjee, and were also compiled and utilized in the project. Although the samples are not representative of all rock types, the data provide some indication of variability in the suite, especially in the quartz diorite and tonalite units. Whole-rock major and trace element chemical analyses were also compiled, including 61 analyses from Ford (1993), 140 from Giles and Chatterjee (1986), 33 from Cameron and Zentilli (1997), 1 from Owen et al. (2010), and 2 from Dostal et al. (2006), as well as the new data for 25 samples from the study of Puchalski (2012).

\section{PLUTONS OF THE TRAFALGAR PLUTONIC SUITE}

Puchalski (2012) divided the Trafalgar Plutonic Suite into twenty separate plutons, each consisting of one of eight different granitoid rock types, as summarized in the legend of Figure 2. Pluton names assigned by earlier workers (Giles and Chatterjee 1986; Ford 1993; White and Scallion 2011) were retained insofar as possible in this study, and additional names assigned as needed using nearby geographic locations. Outcrop is limited in many parts of the area, and aeromagnetic maps (King 1997a, b, c, 2005) helped in the interpretation of pluton boundaries. On these maps, linear magnetic anomalies characterize the host rocks of the Halifax and Goldenville groups, and the plutons show up as circular or elliptical areas of subdued magnetic texture.

Although not unequivocal, features such as cross-cutting relationships, enclaves, and chilled margins observed during mapping enabled an intrusive sequence to be suggested for the suite. The more mafic plutons (Bog Island Lake, Ten Mile Lake, Mink Lake and Porcupine Lake) are inferred to be oldest, followed by the granodioritic pluton (Twin Lakes) and the granodioritic to monzogranitic plutons (West Loon Lake, Pogue Lake, Little Lake and Hattie Lake). This interpretation is supported by the observed presence of a finer-grained chilled margin in the West Loon Lake pluton near its contact with the Twin Lakes pluton which it apparently intruded and separated into two parts (Fig. 2). The large monzogranitic plutons in the eastern and southern parts of the map area (Long John Lake, Seloam Lake, and Moose Lake) are assumed to be next in the intrusive sequence. Although no direct evidence is available, the coarse-grained monzogranite (South Brook pluton) is next in the sequence, followed by porphyritic monzogranite to syenogranite (Bottle Brook Lake and Cameron Settlement Road plutons). However, evidence for magma mingling at the contact between the Bottle Brook and Long John Lake plutons suggests that all these plutons were emplaced at nearly the same time. The youngest plutons in the Trafalgar Plutonic Suite are the fine-grained monzogranite/ syenogranite plutons (Nelson Lake, East Loon Lake, First Rocky Lake, and West River St. Marys). As evident from the map pattern (Fig. 2), the First Rocky Lake pluton intruded the Long John Lake pluton and the Nelson Lake and East Loon Lake plutons intruded the West Loon Lake and Twin Lakes plutons. The West Loon Lake and Twins Lakes plutons are foliated to protomylonitic whereas the syenogranitic plutons that intruded them are undeformed, showing that they post-dated deformation in that area, The position of the Lower Rocky Lake pluton in the intrusive sequence is not constrained by field relations but it is placed before the syenogranitic plutons based on its less evolved composition.

Metasedimentary xenoliths are most abundant in the dioritic, tonalitic, and granodioritic plutons and rare in the more granitic plutons. Xenoliths in the Twin Lake pluton were studied by Scallion (2010) and Scallion et al. (2011) who showed that some are in sharp contact with the granodioritic host whereas others have undergone disaggregation and their contacts are gradational. Some of the disaggregated material resulted in a "mixing" texture with granite which produced discontinuous and irregular layering in the xenolith-rich areas that was mistaken for gneissic layering by some previous workers (Scallion et al. 2011). The xenoliths are interpreted to have been derived from the surrounding Goldenville and Halifax groups. 


\section{ABSOLUTE AGE CONSTRAINTS}

Although cross-cutting relations and other evidence give some indication of the relative ages of the plutonic rocks, available $\mathrm{U}-\mathrm{Pb}$ and ${ }^{40} \mathrm{Ar} /{ }^{39} \mathrm{Ar}$ dates indicate that overall the plutons are of similar age (Fig. 3). Dostal et al. (2006) reported $\mathrm{U}-\mathrm{Pb}$ ages for quartz diorite from the Porcupine Lake pluton (sample LG-122) and granodiorite from the western lobe of the Twin Lakes pluton (sample LG-001) of $373.9 \pm$ 7.2 Ma and $374.3 \pm 3.0 \mathrm{Ma}$, respectively, which are likely to be the ages of igneous crystallization. Another sample (LG120) from the Porcupine Lake pluton yielded similar ages of $376.9 \pm 2.3 \mathrm{Ma}$ for zircon and $374 \pm 3 \mathrm{Ma}$ for monazite (Dostal et al. 2006). Petrographic examination indicated that this sample is a disaggregated xenolith which contains abundant garnet, sillimanite, plagioclase and minor biotite, quartz and spinel, and Dostal et al. (2006) interpreted the ages for both the quartz diorite and xenolith to be the age of granulite-facies metamorphism because these samples were thought to be part of the "Liscomb Gneiss". Based on the work of Scallion et al. (2011), the zircon could be of igneous origin but in either case, the date is probably close to the igneous crystallization age of the Porcupine Lake pluton. An additional constraint on the age of the Trafalgar suite is pro- vided by a $\mathrm{U}-\mathrm{Pb}$ zircon age of $375.0 \pm 4.6 \mathrm{Ma}$ reported by Archibald et al. (2018) for the Kelly Brook pluton, a mylonitic granitoid petrologically similar to Hattie Brook pluton and located $2 \mathrm{~km}$ farther east (Fig. 2).

A range of ${ }^{40} \mathrm{Ar} /{ }^{39} \mathrm{Ar}$ cooling ages has been reported for amphibole, biotite, and muscovite from several of the plutons in the Trafalgar Plutonic Suite (Kontak and Reynolds 1994). These ages indicate the time of cooling of the plutons through the closure temperatures for these minerals $\left(\sim 600^{\circ} \mathrm{C}, \sim 300^{\circ} \mathrm{C}\right.$ and $\sim 400^{\circ} \mathrm{C}$, respectively; Winter 2001$)$, and are summarized on Figure 3. Except for slightly older ages for biotite from the Bog Island Lake, Porcupine Lake, and Twin Lakes plutons, the ages are all within error of, or slightly younger than, the igneous crystallization ages of zircon and monazite from the Porcupine Lake and Twin Lakes plutons. Although dates are not available from every pluton or rock type, they include data from what are likely the oldest (quartz diorite/tonalite plutons) and youngest (East Loon Lake) plutons. The similarity in the dates is consistent with the interpretation that all components of the Trafalgar Plutonic Suite were emplaced at approximately the same time (ca. $374 \mathrm{Ma}$ ), and cooled rapidly through the closure temperatures of amphibole, muscovite, and biotite.

This interpretation is also supported by the work of

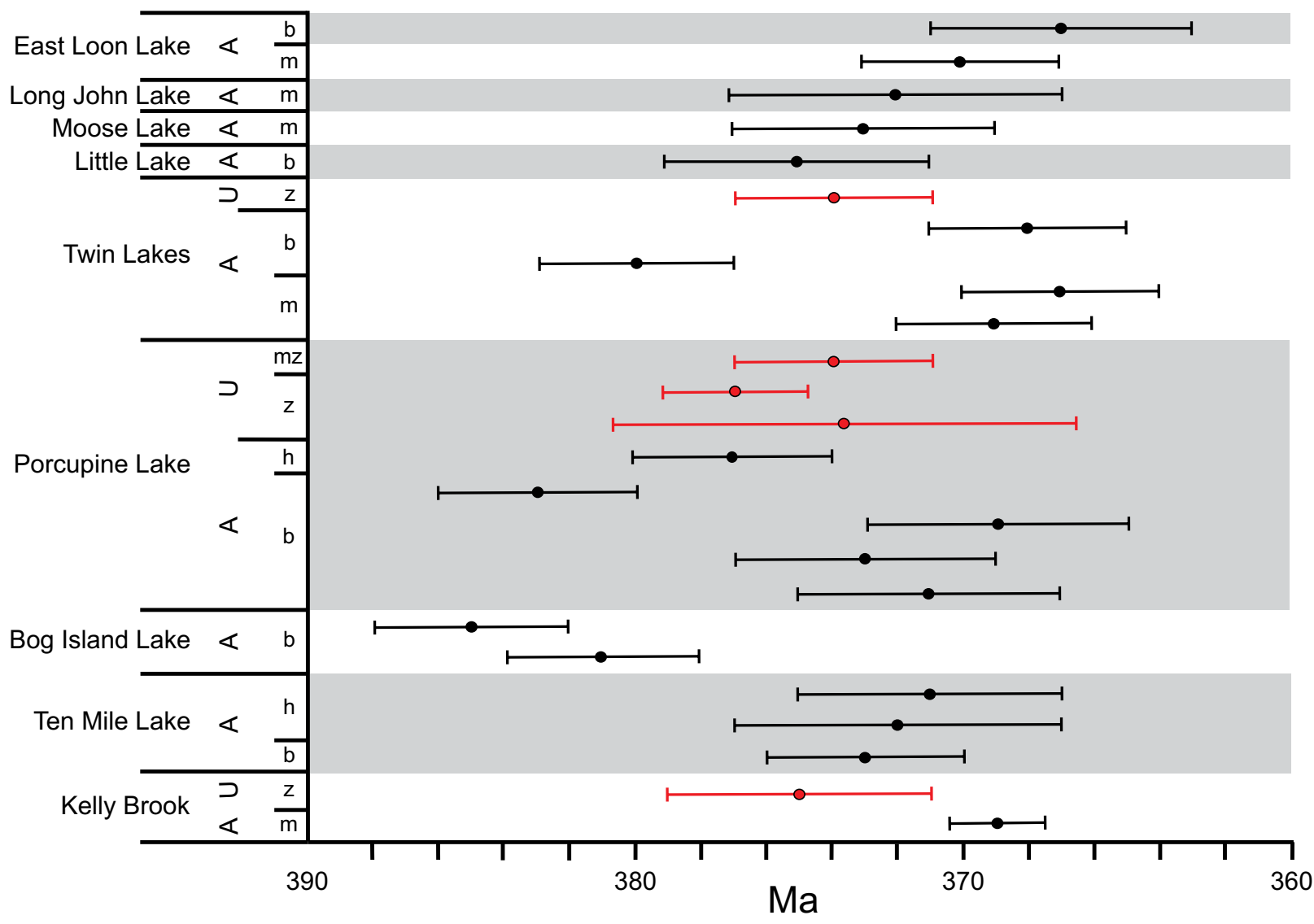

Figure 3. A compilation of $\mathrm{U}-\mathrm{Pb}\left(\mathrm{U}\right.$, in red) and ${ }^{40} \mathrm{Ar} /{ }^{39} \mathrm{Ar}(\mathrm{A})$ dates with error bars for the Trafalgar Plutonic Suite from Dostal et al. (2006) and Kontak and Reynolds (1994) and from the Kelly Brook pluton (Archibald et al. 2018). Mineral abbreviations: b, biotite; $\mathrm{h}$, hornblende; $\mathrm{m}$, muscovite; $\mathrm{mz}$, monazite; $\mathrm{z}$, zircon. 
Archibald et al. (2018) who in addition to the U-Pb zircon age also reported muscovite plateau (cooling) age of $369.0 \pm$ 1.2 Ma from the Kelly Brook pluton. Assuming that the Horton Group north of the fault, which contains Tournaisian fossils, was deposited unconformably on Meguma terrane rocks with cooling ages similar to these plutons, Archibald et al. (2018) calculated high exhumation rates of 0.06 to $0.08 \mathrm{~cm} \mathrm{yr}^{-1}$ for the Meguma terrane.

\section{PETROGRAPHY}

\section{Quartz diorite/tonalite}

The Bog Island Lake, Mink Lake, Ten Mile Lake, and Porcupine Lake plutons all consist mostly of fine- to mediumgrained quartz diorite grading to tonalite (Figs. 4a, 5). Both quartz diorite and tonalite are dominated by plagioclase (50-75\%), with less abundant quartz (10-35\%), biotite $(<15 \%)$, and amphibole $(<25 \%)$. Accessory minerals include apatite, zircon, ilmenite, and rarely garnet. The proportion of biotite and amphibole varies within each pluton and between plutons; most samples contain both minerals but, in some rocks, only biotite, or more rarely only amphibole, is present. K-feldspar is a minor component $(<5 \%)$ in some samples. Texture is typically equigranular but plagioclase forms phenocrysts in some places. THe plagioclase is commonly zoned, with more calcic cores $\left(\mathrm{An}_{50-60}\right)$ and more sodic rims $\left(\mathrm{An}_{30-50}\right)$. Some samples also contain sodic plagioclase.

A large number of amphibole compositions were obtained by A.K. Chatterjee (unpublished data) from a few samples from the quartz diorite and tonalite plutons. Most are classified as magnesio-hornblende to actinolite but some analyses, especially from the Ten Mile Lake pluton, have higher $\mathrm{Na}, \mathrm{K}$, and $\mathrm{Ti}$, and are classified as kaersutite, or have low calcium and are classified as anthophyllite (Puchalski 2012). More systematic study of the amphibole compositions in these plutons is required in order to interpret the significance of the variations.

The Bog Island Lake pluton contains up to 5\% garnet in some samples, and the grains are subhedral to euhedral and as large as $3 \mathrm{~cm}$. Scallion (2010) and Scallion et al. (2011) suggested that the magma had been enriched in manganese as a result of near-complete assimilation of manganiferous xenoliths derived from the Beaverbank Formation, which led to growth of new orthomagmatic and paraxenocrystic garnet.

The Porcupine Lake pluton contains medium- to coarsegrained dioritic enclaves which in places appear to define a magmatic foliation. The Ten Mile Lake pluton, the most southern component of the Trafalgar suite (Fig. 2) has abundant rounded to lenticular enclaves, ranging in size from a few $\mathrm{cm}$ to a few metres that consist of quartz diorite and diorite, as well as metasandstone, andalusite-sillimanite hornfels and coticules derived from the Goldenville and Halifax groups (Scallion 2010). The Ten Mile Lake pluton also in- cludes an area of hornblende gabbronorite sample, but field relations were unclear as to whether this gabbroic rock is a dyke in the pluton, an enclave, or a more mafic component of the pluton itself. Quartz diorite and tonalite samples from the same area of the pluton contain small amounts of relict pyroxene $(<1 \%)$ which forms cores in amphibole and biotite grains.

\section{Granodioritic to granitic plutons}

Based on a combination of texture and estimated modal mineralogy (Fig. 5), the remaining plutons of the Trafalgar Plutonic Suite consist of seven texturally distinct varieties of granodioritic to granitic rocks, including (1) mediumgrained equigranular granodiorite which forms the Twin Lakes pluton (Fig. 4b), (2) medium- to coarse-grained porphyritic granodiorite gradational to monzogranite of the West Loon Lake, Pogue Lake, Little Lake and Hattie Lake plutons (Fig. 4c), (3) fine- to coarse-grained, equigranular monzogranite of the Long John Lake, Moose Lake and Seloam Lake plutons (Fig. 4d), (4) equigranular monzogranite with generally coarser grain size $(\sim 1 \mathrm{~cm}$ in length/diameter) and more abundant quartz (35-48\%) of the South Brook pluton (Fig. 4e), (5) fine- to medium-grained monzogranite gradational to syenogranite with phenocrysts of K-feldspar and quartz of the Bottle Brook Lake and Cameron Settlement Road plutons (Fig. 4f), (6) fine-grained monzogranite of the Lower Rocky Lake pluton (Fig. 4g), and (7) fine-grained monzogranite grading to syenogranite which forms the Nelson Lake, East Loon Lake, First Rocky Lake and West River St. Marys plutons (Fig. 4h).

Quartz forms $35-45 \%$ in all these units and is typically anhedral and interstitial to plagioclase and K-feldspar, except in the Bottle Brook Lake and Cameron Settlement Road plutons where it forms phenocrysts. Undulose extinction and irregular sutured boundaries increase in areas of more deformation. Plagioclase and K-feldspar (microcline) are typically of similar abundance, with plagioclase dominating over microcline in granodioritic rocks. Plagioclase grains tend to be subhedral and myrmekitic texture is common near contacts with K-feldspar. Moderate alteration to saussurite is typical. Hundreds of microprobe analyses of plagioclase in granodioritic and granitic samples (A.K. Chatterjee, unpublished data; Puchalski 2012) show a compositional range from about $\mathrm{An}_{40}$ to $\mathrm{An}_{0}$, with no consistent differences among rock types except a tendency toward more sodic compositions in the syenogranitic samples. Microcline is typically perthitic and poikilitic, with inclusions of biotite, plagioclase and quartz, and weakly altered to sericite. In non-porphyritic rocks, microcline is anhedral but in the porphyritic West Loon Lake, Pogue Lake, Little Lake and Hattie Lake plutons it is subhedral and up to 3-4 times larger than the other mineral grains in the rock (Fig. 4c).

Biotite typically forms less than $4 \%$ in most samples. It is pleochroic from pale brown to dark reddish-brown and has been partially to completely replaced by chlorite. It typically contains abundant inclusions of zircon with pleochroic 

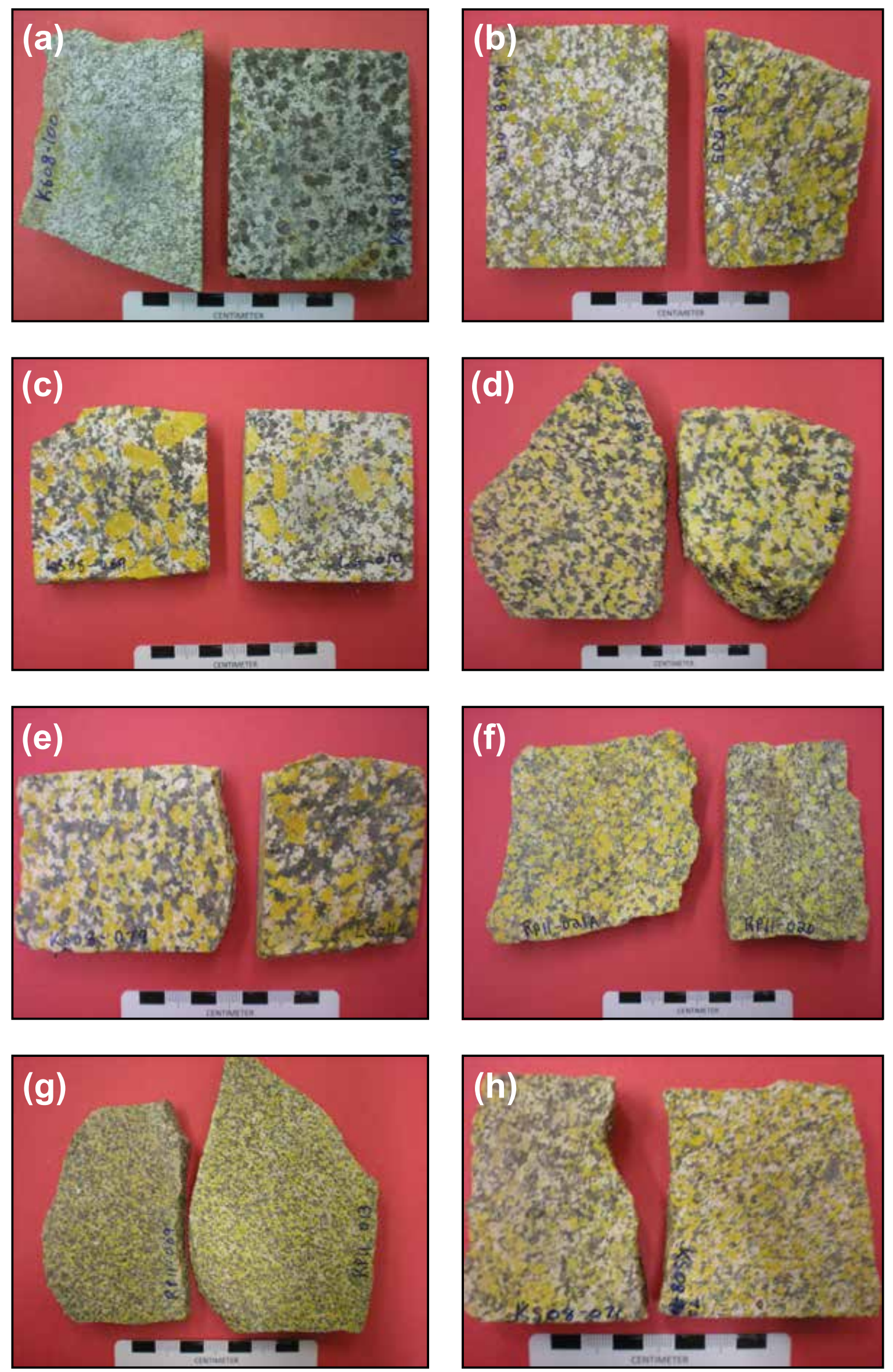
Figure 4. (previous page) Representative samples from plutons of the Trafalgar Plutonic Suite. Slabs have been stained for K-feldspar (yellow) following Hutchinson (1974). Plagioclase is white and quartz is grey. (a) Biotite-amphibole tonalite on left (sample KS08-104) and biotite-amphibole quartz diorite on right (sample KS08-100) from the Bog Island Lake pluton.(b) Granodiorite (sample KS08-014 on left, sample KS08-035 on right) from the Twin Lakes pluton.(c) Megacrystic granodiorite (sample KS08-069 on left, sample LG-010 on right) from West Loon Lake pluton. (d) Equigranular monzogranite (sample 86-076 on left, sample RP11-083 on right) from the Seloam Lake pluton. (e) Coarse-grained monzogranite (sample KS08-079 on left, sample LG-110 on right) from the South Brook pluton. (f) Syenogranite on left (sample RP11-021A) and monzogranite on right (sample RP11-020) with K-feldspar and quartz phenocrysts from the Bottle Brook Lake pluton. (g) Equigranular monzogranite (sample RP11-009 on left, sample RP11-013 on right) from the Lower Rocky Lake pluton. (h) Fine-grained monzogranite (sample KS08-071 on left, sample KS08-072 on right) from the East Loon Lake pluton.

haloes, apatite, and secondary rutile needles. Biotite in the Twin Lakes pluton has higher and more variable $\mathrm{Mn}$ and Ti than in the monzogranitic and syenogranitic plutons. Muscovite tends to be more abundant than biotite in the syenogranitic samples but less abundant than biotite in the other rock types. Its composition is close to endmember muscovite, with little substitution of $\mathrm{Fe}, \mathrm{Mg}$, or $\mathrm{Na}$ (Puchalski 2012).

Accessory minerals include abundant anhedral apatite grains $(<0.5 \mathrm{~mm})$, zircon, and disseminated ilmenite. The zircon occurs almost entirely as inclusions in biotite whereas apatite occurs as both inclusions and separate grains. Garnet is a common accessory mineral in the Twin Lakes pluton, occurring in clusters of small grains or as larger poikilitic crystals. The origin of the garnet in that pluton was studied in detail by Scallion (2010) and Scallion et al. (2011). The presence of coticule xenoliths and small clusters of garnet similar to those in coticules suggest that contamination by the manganiferous Beaverbank Formation contributed to the abundance of garnet in this pluton. According to Scallion et al. (2011), garnet-bearing xenoliths were probably assimilated through a combination of processes, including mechanical disaggregation, melting, and chemical diffusion. Some of the garnet grains were interpreted to be direct xenocrysts, whereas others were interpreted to be paraxenocrystic and orthomagmatic, the formation of which was influenced by assimilation of Mn-rich material into the magma. Garnet is rare in most of the granitic plutons, but where present it is euhedral and $<0.5 \mathrm{~mm}$ in size. The granitic plutons were not included in the study by Scallion (2010) but based on her classification criteria, the garnet is likely to have crystallized from the melt because it has inclusions of igneous minerals such as biotite and forms isolated individual crystals, not associated with other garnet grains.

\section{WHOLE-ROCK GEOCHEMISTRY}

\section{Major and trace elements}

The compiled chemical data include analyses for two hundred and eleven samples representing all plutons of the Trafalgar suite. However, the data are from several different sources going back to the 1980 s, and hence vary in quality and in the range of trace elements analyzed. The most complete analyses were done by Puchalski (2012) at ACME Laboratory (now Bureau Veritas) in Vancouver, BC. These analyses represent most of the granitic plutons and rock types,

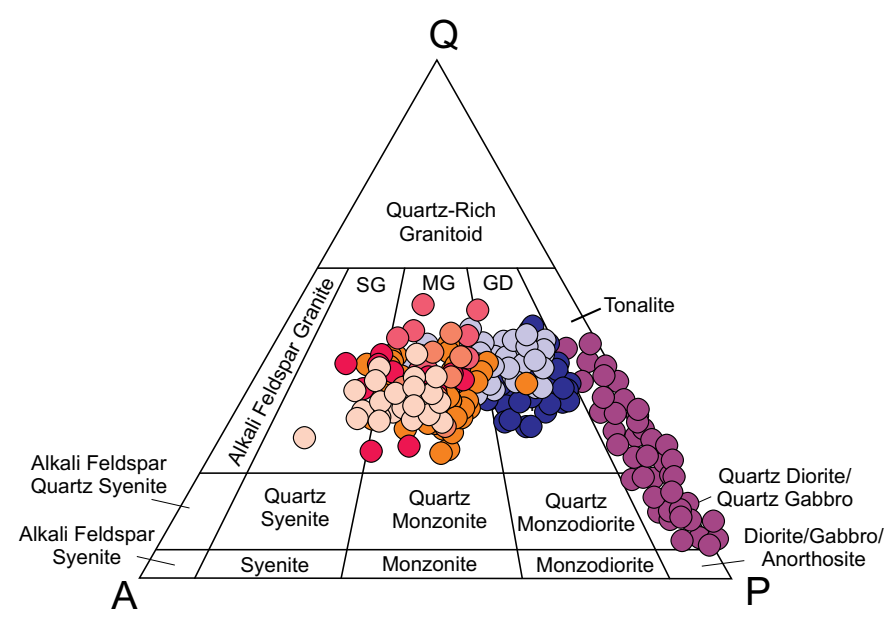

Quartz diorite/tonalite

(Bog Island Lake, Mink Lake, Ten Mile Lake, Porcupine Lake; n=63)

- Granodiorite

(Twin Lakes pluton; $\mathrm{n}=26$ )

Porphyritic monzogranite to granodiorite (West Loon Lake, Pogue Lake, Little Lake; Hattie Lake; n=52)

- Equigranular monzogranite (Long John Lake, Seloam Lake, Moose Lake; n=65)

Coarse-grained monzogranite (South Brook pluton; $n=10$ )

- Porphyritic monzogranite to syenogranite (Bottle Brook Lake, Cameron Settlement Road; n=13)

Fine-grained monzogranite (Lower Rocky Lake pluton; $n=9$ )

Fine-grained monzogranite to syenogranite (Nelson Lake, East Loon Lake, First Rocky Lake, West River St. Marys; $n=31$ )

Figure 5. Modal compositions of samples from the Trafalgar Plutonic Suite plotted on the classification diagram of Streckeisen (1976). Proportions of modal quartz (Q), alkali feldspar (A), and plagioclase $(\mathrm{P})$ were estimated from stained slabs and thin sections. 
but none is from the Twin Lakes granodiorite and only one is from a quartz dioritic/tonalitic pluton.

The quartz dioritic and tonalitic plutons show wide range in $\mathrm{SiO}_{2}$ from about $50 \%$ in gabbroic/dioritic samples to $66 \%$ in tonalitic samples with average $\mathrm{SiO}_{2}$ contents of 54.7, 52.2, 58.4 , and $61 \%$ in analyzed samples from the Ten Mile Lake, Bog Island Lake, Porcupine Lake, and Mink Lake plutons, respectively (Fig. 6). In contrast to these more mafic plutons, the granodioritic/granitic plutons have average $\mathrm{SiO}_{2}$ of about $70 \%$, and the granitic plutons average about $72-73 \%$ $\mathrm{SiO}_{2}$ (Fig. 6).

Major element oxides are plotted against $\mathrm{SiO}_{2}$ in Figure 7 to illustrate chemical variation in the plutons. Six samples from the Ten Mile Lake and Bog Island Lake plutons contain between 46 and $50 \% \mathrm{SiO}_{2}$ and are plotted on the vertical axis on Figure 7. Also shown on the figure for comparison are fields for chemical analyses from the Canso plutons of Hill (1991), South Mountain Batholith, and other granitoid plutons in the Meguma terrane based on the compilation of Tate and Merrett (1994) and Tate (1995). Most major element oxides show scattered negative correlation with $\mathrm{SiO}_{2}$ (Fig. 7). Exceptions are $\mathrm{Na}_{2} \mathrm{O}$ and $\mathrm{K}_{2} \mathrm{O}$, which display pos- itive correlation, and $\mathrm{P}_{2} \mathrm{O}_{5}$ which is approximately constant across the range of $\mathrm{SiO}_{2}$ (Fig. 7). It is apparent that the dioritic to tonalitic plutons show wide variation which at least in part is the result of the presence of abundant xenoliths of metasedimentary rocks (Scallion 2010; Puchalski 2012). Because of their variability, the fact that they were not sampled during the present study and hence that the abundance of xenoliths in analyzed samples is unknown, and the lack of modern geochemical data from those units, a detailed assessment of their geochemistry is not included here. Similar tonalitic rocks occur in the Canso plutons (Hill 1991), as indicated by the lower $\mathrm{SiO}_{2}$ parts of the fields defined by those samples from the database of Tate (1995). However, none are as low in $\mathrm{SiO}_{2}$ as the dioritic plutons associated with the Trafalgar suite (Fig. 7).

The granodioritic and granitic plutons show more chemical similarity, and the majority of samples cluster quite closely; generally, the textural differences among the plutons are not reflected in chemical differences. Their chemical compositions and trends are similar to those of the South Mountain Batholith and other granitic plutons of the Meguma terrane, including the Canso plutons. Also similar

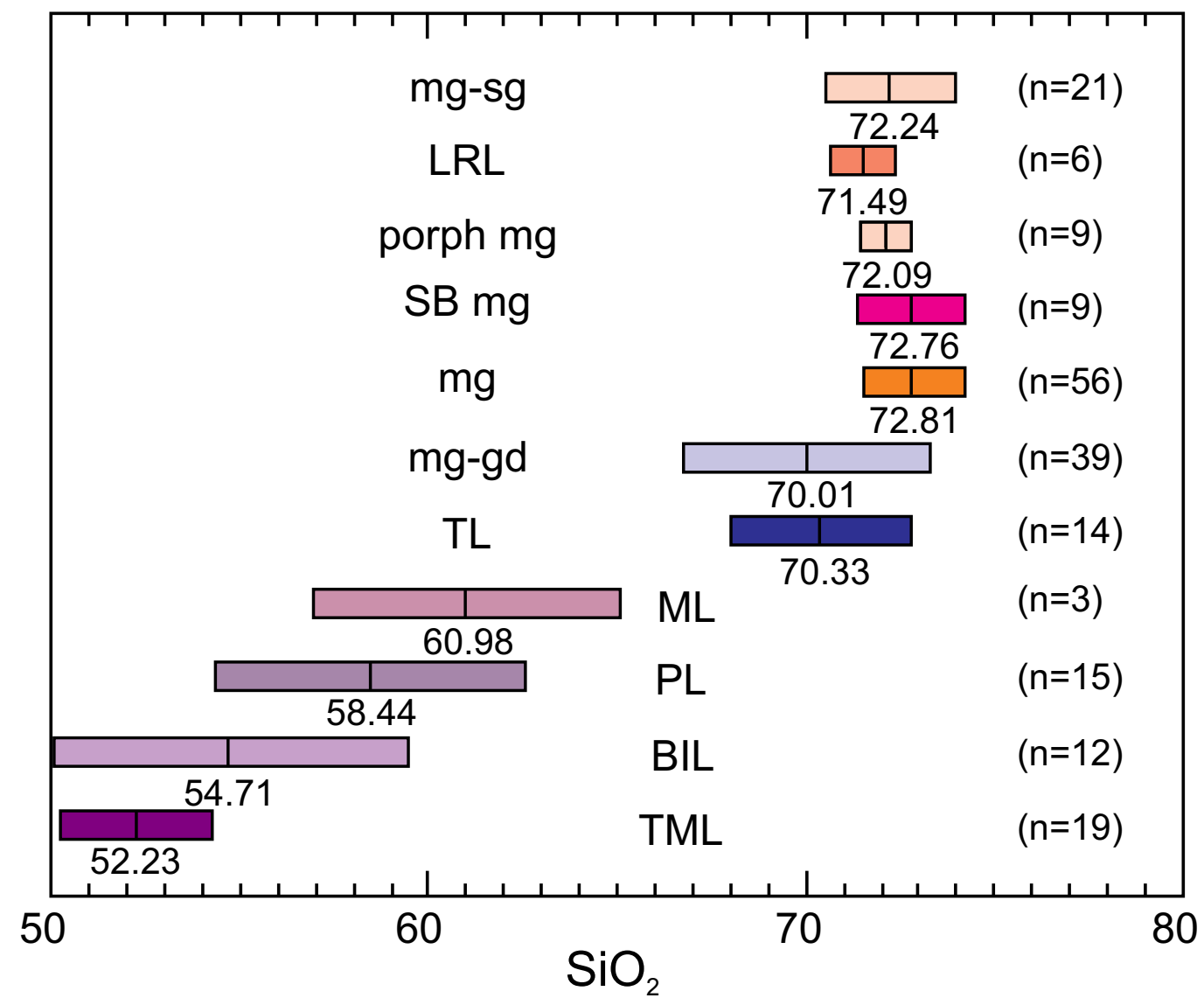

Figure 6. Diagram illustrating mean and standard deviation of $\mathrm{SiO}_{2}$ content in analyzed samples from the main rock types of the Trafalgar Plutonic Suite. Abbreviations from bottom to top: TML, Ten Mile Lake pluton; BIL, Bog Island Lake pluton; PL, Porcupine Lake pluton; ML, Mink Lake pluton; TL, Twin Lakes pluton; mg-gd, monzogranite-granodiorite; mg, monzogranite; SB mg, South Brook monzogranite; porph mg, porphyritic monzogranite; LRL, Lower Rocky Lake pluton; mg-sg, monzogranite-syenogranite. 

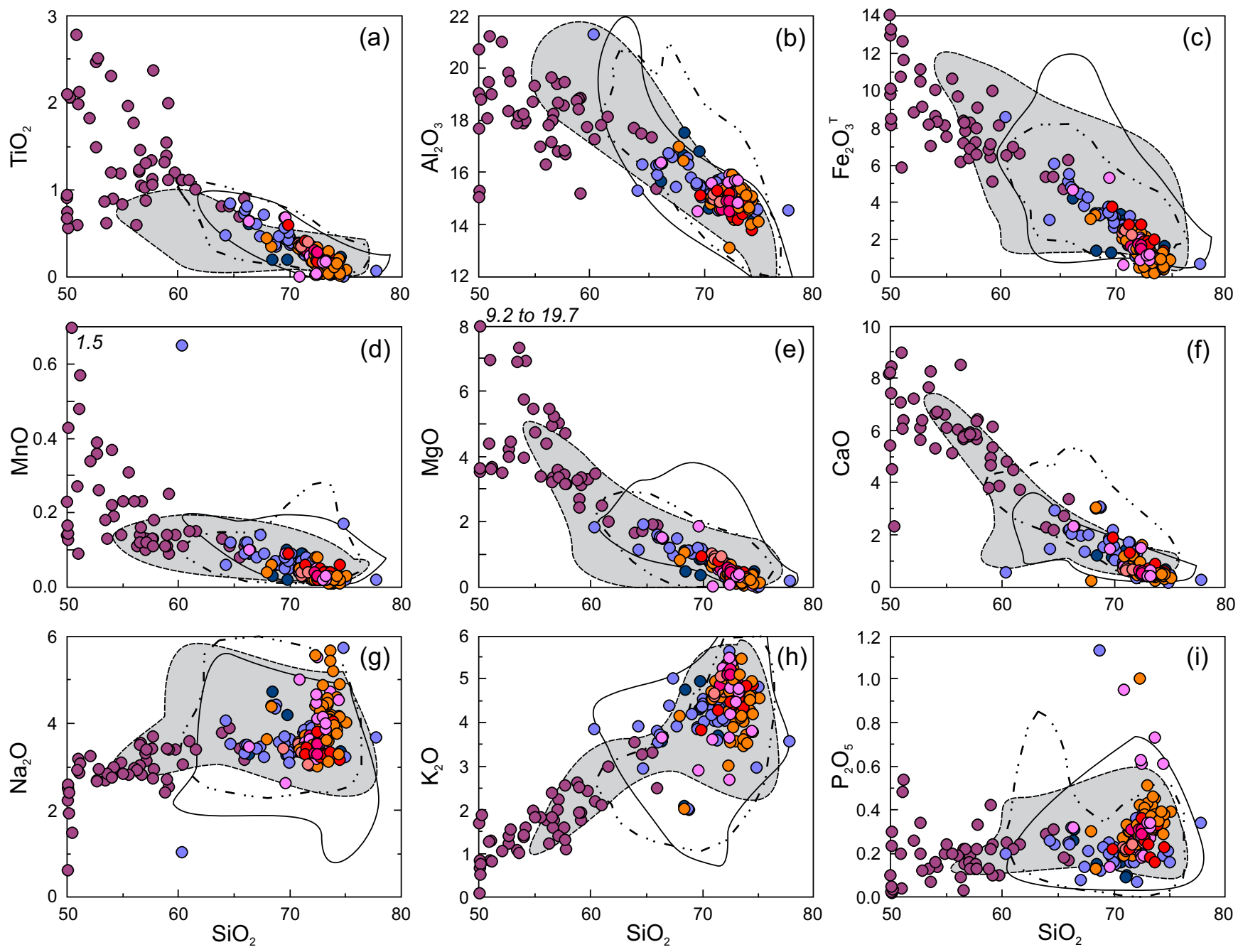

Figure 7. Plots of major element oxides against $\mathrm{SiO}_{2}$ to illustrate chemical variation in the Trafalgar Plutonic Suite. Symbols for Trafalgar suite plutons are as in Figure 5. Six dioritic samples with $46-50 \% \mathrm{SiO}_{2}$ are plotted on the y-axis of the diagrams. Five samples have $\mathrm{MgO}$ more than 8, as shown. Fields for the Canso plutons of Hill (1991) (dashed outline with grey fill), South Mountain Batholith (solid outline), and other Meguma terrane plutons (dashed-dotted outline) are based on data from Tate and Merrett (1994) and Tate (1995).

are high $\mathrm{Rb}$ (Fig. 8a), correlative with potassium, and the decrease in $\mathrm{Ba}$ and $\mathrm{Sr}$ with increasing $\mathrm{SiO}_{2}$ (Figs. 8b, c). Such variations, like those in the major element oxides, are indicative of strong control by feldspars and micas during magma evolution, as demonstrated by Puchalski (2012) using Pearce Element Ratio analysis (e.g., Pearce 1968; Stanley 2017). The more immobile elements $\mathrm{Nb}, \mathrm{Y}$, and $\mathrm{Zr}$ also show similar patterns in the Trafalgar suite as in other Meguma terrane plutons, and typically decrease with increasing $\mathrm{SiO}_{2}$ (Figs. $8 \mathrm{c}, \mathrm{d}, \mathrm{e})$ likely related to fractionation of accessory phases such as zircon, monazite, and apatite as inclusions in biotite.

Most samples are only weakly to moderately peraluminous, with $\mathrm{A} / \mathrm{CNK}$ ratios more than 1 but less than 1.2 (Fig. 9). This is consistent with the ubiquitous presence of the moderately peraluminous minerals biotite and muscovite and rarely garnet, but absence of highly peraluminous magmatic minerals such as cordierite and andalusite, in contrast to the common presence of those minerals in the highly peraluminous granite in South Mountain Batholith (Clarke 2019).

Although REE patterns in the granodiorite and granite plutons are broadly similar, the total REE abundance shows a slight decrease in the younger units and the Eu anomaly $\left(\mathrm{Eu} / \mathrm{Eu}^{*}\right)$ becomes progressively larger (Fig. 10). Similar trends of decreasing REE with magma evolution were explained in units of the South Mountain Batholith by fractionation of plagioclase and biotite (Muecke and Clarke 1981). Part of the effect may be due to removal of zircon, monazite, and other REE-bearing accessory phases during biotite fractionation, and those minerals typically occur as inclusions in biotite.

The trends in major element data in the granodioritic and granitic plutons of the Trafalgar Plutonic Suite (Fig. 7) are consistent with evolution from the same or similar parent magma by fractionation of minor biotite, sodic plagioclase $\left(\mathrm{An}_{20}\right)$, muscovite and $\mathrm{K}$-feldspar and enrichment 

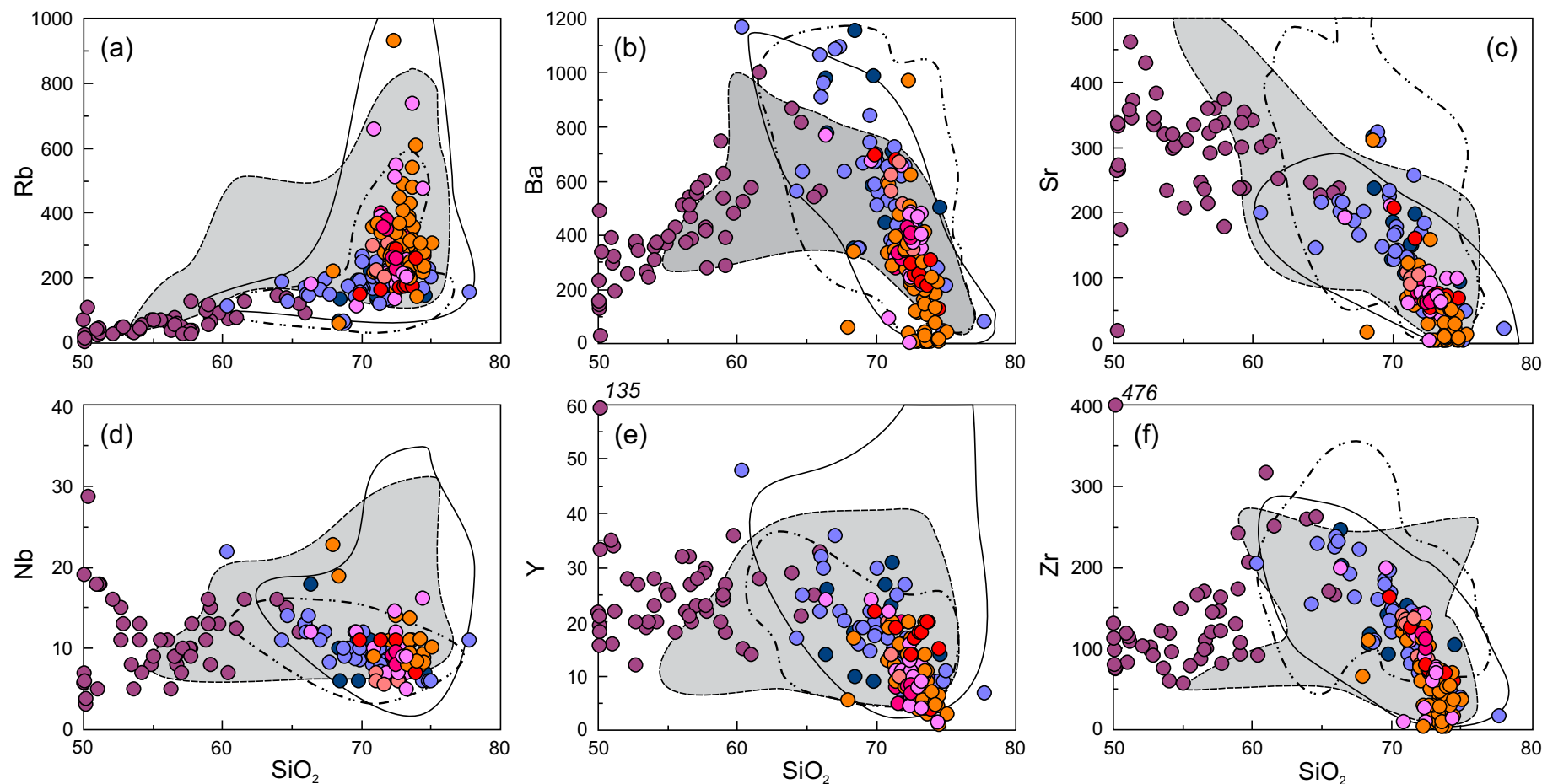

Figure 8. Plots of selected trace elements against $\mathrm{SiO}_{2}$ to illustrate chemical variation in the Trafalgar Plutonic Suite. Symbols for Trafalgar suite plutons are as in Figure 5. Six dioritic samples with $46-50 \% \mathrm{SiO}_{2}$ are plotted on the y-axis of the diagrams. Two of these samples have $\mathrm{Y}$ and $\mathrm{Zr}$ above the scale of the diagram, as shown. Fields for the Canso plutons of Hill (1991) (dashed outline with grey fill), South Mountain Batholith (solid outline), and other Meguma terrane plutons (dashed-dotted outline) are based on data from Tate and Merrett (1994) and Tate (1995).

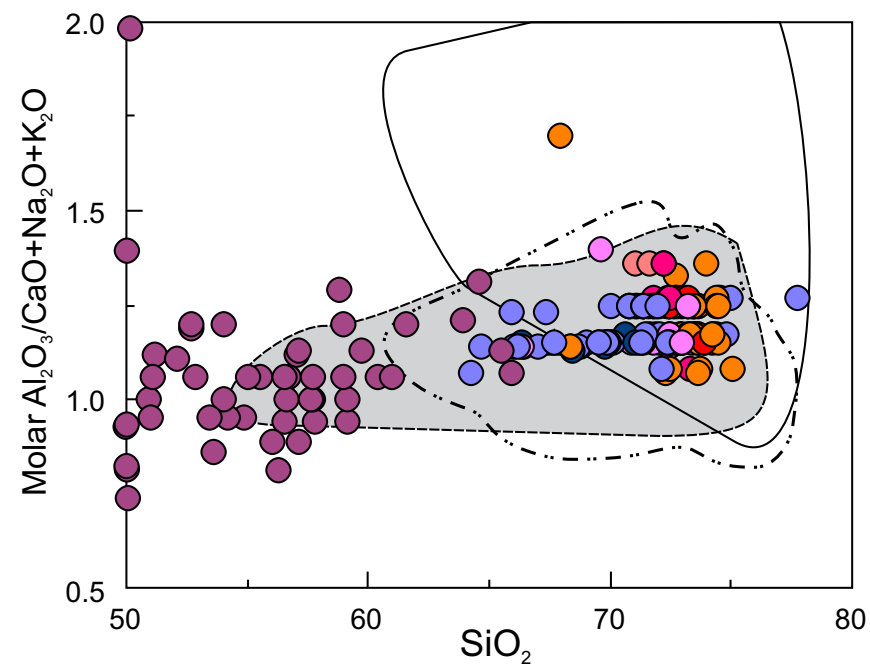

Figure 9. Plot of molar $\mathrm{Al}_{2} \mathrm{O}_{3} / \mathrm{CaO}+\mathrm{Na}_{2} \mathrm{O}+\mathrm{K}_{2} \mathrm{O}$ against $\mathrm{SiO}_{2}$ for samples from the Trafalgar Plutonic Suite (symbols as in Figure 5). Six dioritic samples with $46-50 \% \mathrm{SiO}_{2}$ are plotted on the $y$-axis of the diagram. One of these samples is above the scale of the diagram, as shown. Fields for the Canso plutons of Hill (1991) (dashed outline with grey fill), South Mountain Batholith (solid outline), and other Meguma terrane plutons (dashed-dotted outline) are based on data from Tate and Merrett (1994) and Tate (1995). in quartz, as demonstrated by Puchalski (2012) using Pearce Element Ratio modelling (data not shown here). Puchalski (2012) also suggested that the tonalite/quartz diorite plutons are more varied in composition than the more felsic plutons and show less coherent inter-element correlations, and hence may not be co-magmatic with the felsic plutons. Ferromagnesian minerals such as biotite and hornblende and more calcic plagioclase were more involved in the evolution of the tonalite/quartz diorite magmas (Puchalski 2012).

\section{Isotopic compositions}

Although no new isotopic data were obtained by Puchalski (2012), samples from the Trafalgar area had been analysed previously for $\mathrm{Sm}, \mathrm{Nd}, \mathrm{Rb}$, and $\mathrm{Sr}$ isotopes by Clarke et al. (1993). Based on the locations of those samples with respect to the map units of this study (Fig. 2), most of the analyses (eleven) are from samples of the dioritic-tonalitic plutons (Fig. 11). They define a trend from positive $(+3.8)$ to negative $(-5) \varepsilon N d$ with increasing ${ }^{87} \mathrm{Sr} /{ }^{86} \mathrm{Sr}$ ratios from 0.703 to 0.709 (Fig. 11). Four granodioritic and monzogranite samples from the Twin Lakes, West Loon Lake, and Moose Lake plutons all have negative $\varepsilon N d$ values ( -1.67 to -5.96$)$ and ${ }^{87} \mathrm{Sr} /{ }^{86} \mathrm{Sr}$ ratios of 0.707 to 0.709 . Samples from three metasedimentary xenoliths in the plutons and from the Halifax and Goldenville groups all have more negative $\varepsilon \mathrm{Nd}$ values and higher ${ }^{87} \mathrm{Sr} /{ }^{86} \mathrm{Sr}$ ratios. The well-defined trend on 

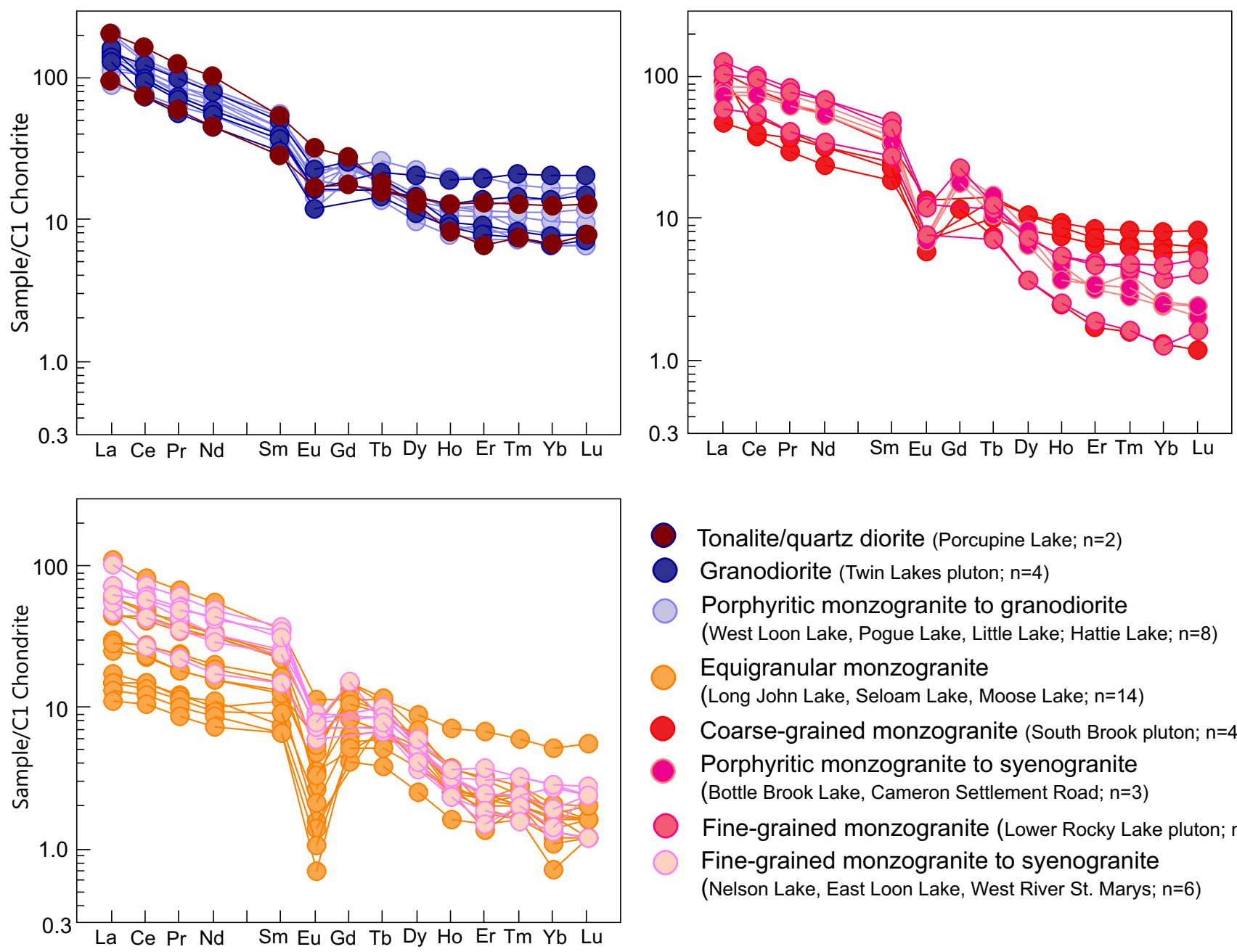

Tonalite/quartz diorite (Porcupine Lake; $n=2$ )

Granodiorite (Twin Lakes pluton; $n=4$ )

Porphyritic monzogranite to granodiorite

(West Loon Lake, Pogue Lake, Little Lake; Hattie Lake; n=8)

Equigranular monzogranite

(Long John Lake, Seloam Lake, Moose Lake; $n=14$ )

Coarse-grained monzogranite (South Brook pluton; $n=4$ )

Porphyritic monzogranite to syenogranite

(Bottle Brook Lake, Cameron Settlement Road; $n=3$ )

Fine-grained monzogranite (Lower Rocky Lake pluton; n=3)

Fine-grained monzogranite to syenogranite

(Nelson Lake, East Loon Lake, West River St. Marys; $n=6$ )

Figure 10. Chondrite-normalized rare-earth element (REE) data for samples from the Trafalgar Plutonic Suite. Chondrite-normalizing values are from Sun and McDonough (1989).

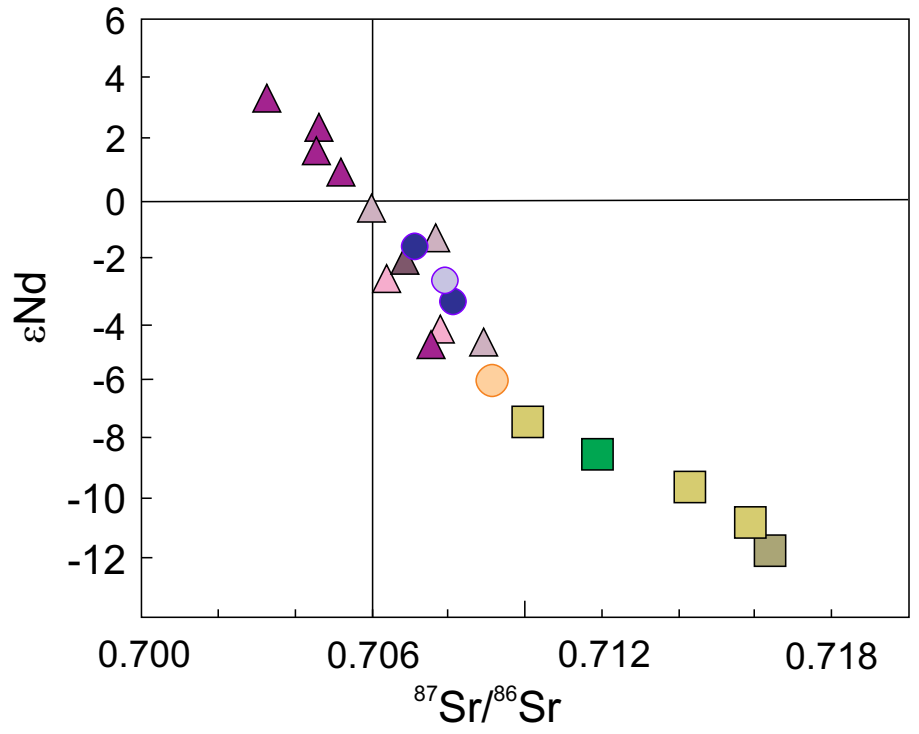

Trafalgar Plutonic Suite

Twin Lakes pluton $(n=2)$

West Loon Lake pluton $(n=1)$

Moose Lake pluton $(n=1)$

$\triangle$ Porcupine Lake tonalite/diorite) $(n=3)$

$\triangle$ Bog Island Lake quartz diorite $(\mathrm{n}=2)$

$\triangle$ Mink Lake tonalite $(n=1)$

$\triangle$ Ten Mile Lake quartz diorite/amphibole rock) $(n=5)$

Metasedimentary samples

Metasedimentary xenoliths $(n=3)$

Halifax Group $(n=1)$

Goldenville Group $(n=1)$

Figure 11. Plot of $\varepsilon N d$ against ${ }^{87} \mathrm{Sr} /{ }^{86} \mathrm{Sr}$ ratios for samples from the Trafalgar area published by Clarke $e$ al . (1993) using map units as defined by Puchalski (2012). Map unit assignments are based on sample locations and descriptions published by Clarke et al. (1993). 
this diagram is consistent with contamination of magmas that formed the Trafalgar suite by metasedimentary material from the Goldenville and Halifax groups. This conclusion is supported by the observation that monzogranite sample LG-004 from the collection of Giles and Chatterjee (1986) from the Moose Lake pluton has the most negative $\varepsilon \mathrm{Nd}$ value and highest ${ }^{87} \mathrm{Sr} /{ }^{86} \mathrm{Sr}$ ratio of the plutonic rocks and contains obvious xenolithic metasedimentary material consistent with that interpretation. It is also consistent with other studies (e.g., MacDonald and Clarke 2017) which have demonstrated that such contamination is widespread in Meguma terrane plutons.

\section{TECTONIC SETTING}

Based on studies elsewhere in the Meguma terrane, the Goldenville and Halifax groups were deformed and variably metamorphosed (greenschist- to amphibolite-facies) during the Early to Middle Devonian Neoacadian orogeny at ca. 400-390 Ma (Hicks et al. 1999). The abundant granitoid plutons that characterize the terrane were emplaced mainly during the waning stages of that orogenic event (e.g., White and Barr 2012). However, neither the nature of the orogenic event nor the tectonic setting of the voluminous granitic plutons is well understood in detail (e.g., Tate and Clarke 1995; Moran et al. 2007; White and Barr 2012). Like other granitoid plutons of the Meguma terrane, the granodioritic and granitic samples from the Trafalgar Plutonic Suite plot mainly in the volcanic-arc/syn-collisional field on the Rb$\mathrm{Y}+\mathrm{Nb}$ tectonic setting discrimination diagram of Pearce et al. (1984) for granitoid rocks (Fig. 12a). On the Y-Nb diagram (Fig. 12b), they are mainly in the volcanic-arc field with only minor scatter into the syn-collisional field. Moran et

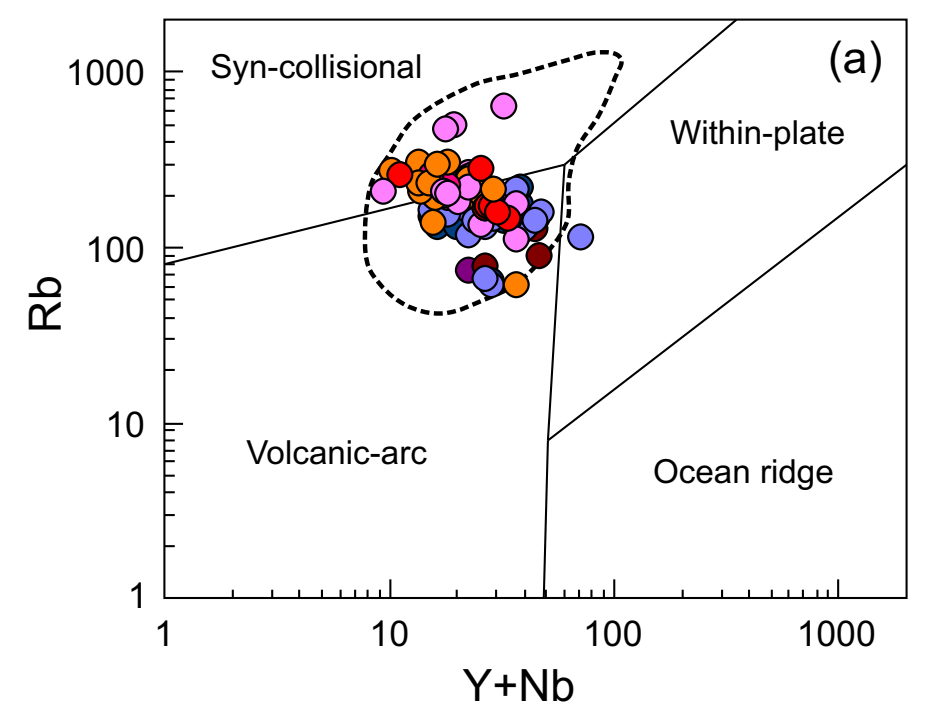

al. (2007), following van Staal (2007), invoked west-dipping subduction and slab break-off prior to oblique closure of oceanic crust separating Meguma terrane and Gondwana in the Early Carboniferous. The model implies large-scale crustal melting and/or extensive crustal contamination of mantle-derived mafic magmas of which the dioritic/tonalitic plutons of the Trafalgar suite may be examples similar to those documented elsewhere by Tate (1995) and Tate and Clarke (1995).

The fact that the Meguma terrane was still an unknown distance offshore in the Middle to Late Devonian compared to its present location (Waldron et al. 2015) is a major contributing factor in the uncertainty in tectonic models. Movement on numerous major shear zones, including the northern margin of the Trafalgar Plutonic Suite, continued through the Carboniferous related to dextral transpressive motion of the Meguma terrane against adjacent Avalonia along the Cobequid-Chedabucto fault system (Murphy et al. 2011).

\section{CONCLUSIONS}

Mapping and petrological studies have demonstrated that the Trafalgar Plutonic Suite consists mainly of granitic and granodioritic plutons with textural, mineralogical, and chemical similarities to plutons of similar late Devonian age elsewhere in the Meguma terrane. Tonalitic and dioritic plutons are a minor component in the suite and have an uncertain relationship to the more felsic rocks. Both the tonalitic/dioritic and granodioritic/granitic rocks show chemical and isotopic evidence of extensive contamination by metasedmentary rocks including those of the host Goldenville and Halifax groups. More detailed studies, especially of

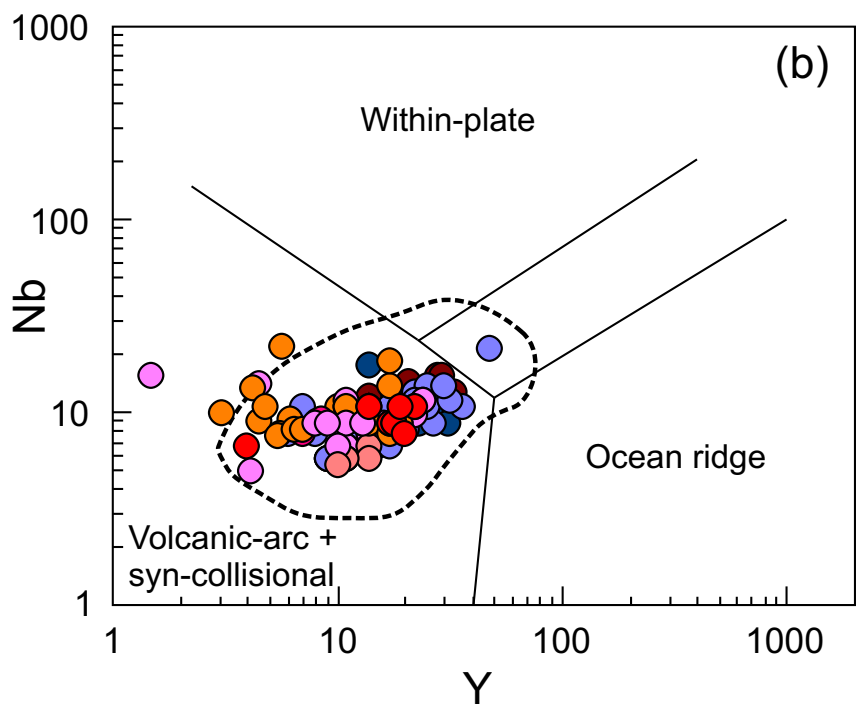

Figure 12. Samples from the Trafalgar Plutonic Suite with $>60 \% \mathrm{SiO}_{2}$ plotted on the tectonic setting discrimination diagrams for granitoid rocks of Pearce et al. (1984). Fields on each diagram enclose granitic samples with $>60 \% \mathrm{SiO}_{2}$ from Canso plutons of Hill (1991), South Mountain Batholith, and other Meguma terrane plutons from Tate and Merrett (1994) and Tate (1995). 
the dioritic and tonalitic plutons, are needed in order to better understand Late Devonian magmatism in the Meguma terrane and to develop a robust tectonic model that includes all plutons of the terrane, including the Trafalgar Plutonic Suite.

\section{ACKNOWLEDGEMENTS}

This paper is derived from the MSc thesis project of the first author. This work was funded in part by a NSERC Discovery Grant to Sandra Barr, and an Acadia Graduate Award to Raya Puchalski. We thank journal reviewer Donnelly Archibald, an anonymous journal reviewer, and journal editor David West for their comments and suggestions which resulted in a clearer focus for this contribution.

\section{REFERENCES}

Archibald, D.B., Murphy, J.B., Reddy, S.M., Jourdan, F., Gillespie, J., and Glorie, S. 2018. Post-accretionary exhumation of the Meguma terrane relative to the Avalon terrane in the Canadian Appalachians. Tectonophysics, 747-748, pp.343-356. https://doi.org/10.1016/j.tecto.2018.10.016

Cameron, B. and Zentilli, M. 1997. Geochemical characterization of the mineralized transition between the Goldenville and Halifax formations and the interaction with adjacent granitoid plutons. Atlantic Geology, 33, pp.143155. https://doi.org/10.4138/2065

Clarke, D.B. 2019. The origins of strongly peraluminous granitoid rocks. The Canadian Mineralogist, 57, pp. 529550. https://doi.org/10.3749/canmin. 1800075

Clarke, D. B. 2007. Assimilation of xenocrysts in granitic magmas: principles, processes, proxies, and problems. The Canadian Mineralogist, 45, pp. 5-30. https://doi. org/10.2113/gscanmin.45.1.5

Clarke, D. B., Chatterjee, A. K., and Giles, P. S. 1993.Petrochemistry, tectonic history, and Sr-Nd systematics of the Liscomb Complex, Meguma Lithotectonic Zone, Nova Scotia. Canadian Journal of Earth Sciences, 30, pp. 449464. https://doi.org/10.1139/e93-033

Dostal, J., Keppie, D. J., Jutras, P., Miller, B. V., and Murphy, B. 2006. Evidence for the granulite-granite connection: Penecontemporaneous high-grade metamorphism, granitic magmatism and core complex development in the Liscomb Complex, Nova Scotia, Canada. Lithos, 86, pp. 77-99. https://doi.org/10.1016/j.lithos.2005.04.002

Erdmann, S., London, D., Morgan IV, G. B. and Clarke, D. B. 2007. The contamination of granitic magma by metasedimentary country-rock material: an experimental study. The Canadian Mineralogist, 45, pp. 43-61. https://doi. org/10.2113/gscanmin.45.1.43

Erdmann, S., Jamieson, R. A., and MacDonald, M. A. 2009. Evaluating the origin of garnet, cordierite, and biotite in granitic rocks: a case study from the South Mountain Ba- tholith. Journal of Petrology, 50, pp. 1477-1503. https:// doi.org/10.1093/petrology/egp038

Faribault, E. R. 1897. Fifteen Mile Stream, Halifax and Guysborough counties, Nova Scotia. Geological Survey of Canada, Map Sheet 41, scale 1:63 360.

Fletcher, H. 1887. Report of the geological surveys and exploration in the counties of Guysborough, Antigonish, and Pictou; Geological and Natural History Survey of Canada, Report of the Geological Surveys and Explorations in the counties of Guysborough, Antigonish, and Pictou from 1882 to 1886, part P, pp. 5-163. https://doi. org/10.4095/296717

Fletcher H. and Faribault, E.R. 1901. Trafalgar sheet, Halifax, Pictou and Guysborough counties. Geological Survey of Canada Map 42, scale 1:63 360. https://doi. org/10.4095/107904

Ford, K. L.1993. Radioelement mapping of parts of the Musquodoboit Batholith and Liscomb Complex, Meguma Zone, Nova Scotia. In Mineral deposit studies in Nova Scotia, vol., 2. Edited by A.L. Sangster. Geological Survey of Canada, Paper, 91-09, pp. 71-111 (and unpublished data). https://doi.org/10.4095/183990

Giles, P. S. and Chatterjee, A. K. 1986. Peraluminous granites of the Liscomb Complex. Nova Scotia Department of Mines and Energy, Information Series No.12, pp. 83-89.

Giles, P. S., Chatterjee, A. K., and Ford, K. L. 2008. Bedrock geology map of the Liscomb Complex (parts of NTS sheets 11E/01, 11E/02, 11E/07, and 11E/08), Nova Scotia. Nova Scotia Department of Natural Resources, Open File Map ME 2008-4, scale 1:50 000.

Hibbard, J.P., van Staal, C.R., Rankin, D.W., and Williams, H. 2006. Lithotectonic map of the Appalachian Orogen, Canada-United States of America. Geological Survey of Canada, Map 2096A, scale 1:1 500 000. https://doi. org/10.4095/221932

Hicks, R.J., Jamieson, R.A., and Reynolds, P.H. 1999. Detrital and metamorphic ${ }^{40} \mathrm{Ar} /{ }^{39} \mathrm{Ar}$ ages from muscovite and whole-rock samples, Meguma Supergroup, southern Nova Scotia. Canadian Journal of Earth Sciences, 36, pp. 23-32. https://doi.org/10.1139/e98-081

Hill, J.D. 1991. Petrology, tectonic setting, and economic potential of Devonian peraluminous granitoid plutons in the Canso and Forest Hill areas, eastern Meguma terrane, Nova Scotia. Geological Survey of Canada, Bulletin 383, 96 p. https://doi.org/10.4095/131924

Hutchinson, C.S. 1974. Laboratory handbook of petrographic techniques. Wiley Interscience, New York, 527 p.

Jamieson, R.A., Hart, G.G., Chapman, G.G., and Tobey, N.W. 2012. The contact aureole of the South Mountain Batholith in Halifax, Nova Scotia: geology, mineral assemblages, and isograds. Canadian Journal of Earth Sciences, 49, pp. 1280-1296. https://doi.org/10.1139/e2012-058

King, M. S. 1997a. Meguma Terrane, enhanced (second vertical derivative) aeromagnetic digital data for NTS 11E/02, Upper Musquodoboit, Halifax, Guysborough and Colchester counties, Nova Scotia. Nova Scotia Department of Natural Resources, Minerals and Energy 
Branch, Open File Map 97-014, scale 1:50 000.

King, M. S. 1997b. Meguma Terrane, enhanced (second vertical derivative) aeromagnetic digital data for NTS $11 \mathrm{E} / 01$, Liscomb, Guysborough and Halifax counties, Nova Scotia. Nova Scotia Department of Natural Resources, Minerals and Energy Branch, Open File Map 97013, scale 1:50 000 .

King, M. S. 1997c. Meguma Terrane, enhanced (second vertical derivative) aeromagnetic digital data for NTS 11E/08, Lochaber, Pictou, Guysborough and Antigonish counties, Nova Scotia. Nova Scotia Department of Natural Resources, Minerals and Energy Branch, Open File Map 97-017, scale 1:50 000.

King, M. S. 2005. Airborne magnetic calculated second vertical derivative map for NTS 11E/07, Hopewell Area, Nova Scotia. Nova Scotia Department of Natural Resources, Minerals and Energy Branch, Open File Map ME 2005-043, scale 1:50 000.

Kontak, D. J. and Reynolds, P. H. 1994. ${ }^{40} \mathrm{Ar} /{ }^{39} \mathrm{Ar}$ dating of metamorphic and igneous rocks of the Liscomb Complex, Meguma Terrane, southern Nova Scotia, Canada. Canadian Journal of Earth Sciences, 31, pp. 1643-1653. https://doi.org/10.1139/e94-146

Macdonald, M.A. and Clarke, D.B. 2017. Occurrence, origin, and significance of melagranites in the South Mountain Batholith, Nova Scotia. Canadian Journal of Earth Sciences, 54, pp. 693-713. https://doi.org/10.1139/cjes2016-0106

MacLean, N.J., Barr, S.M., White, C.E., Ketchum, J.W.F. 2003. New U-Pb (zircon) age and geochemistry of the Wedgeport Pluton, Meguma terrane, Nova Scotia. Atlantic Geology, 39, pp. 239-253. https://doi.org/10.4138/1184

Mahoney, K. L. 1996. The contact metamorphic aureole of the South Mountain Batholith, Nova Scotia. Unpublished M.Sc. thesis, Acadia University Wolfville, Nova Scotia, $153 \mathrm{p}$.

Moran, P. C., Barr, S. M., White, C. E., and Hamilton, M. A. 2007. Petrology, age, and tectonic setting of the Seal Island Pluton, offshore southwest Nova Scotia. Canadian Journal of Earth Sciences, 44, pp. 1467-1478. https://doi. org/10.1139/e07-023

Muecke, G.K. and Clarke, D.B. 1981. Geochemical evolution of the South Mountain Batholith, Nova Scotia; rare-earth-element evidence. The Canadian Mineralogist, 19, pp. 133-145.

Murphy, J.B., Waldron, J.W.F., Kontak, D.J., Pe-Piper, G., and Piper, D.J.W. 2011. Minas Fault Zone: Late Paleozoic history of an intra-continental orogenic transform fault in the Canadian Appalachians. Journal of Structural Geology, 33, pp. 312-328. https://doi.org/10.1016/j. jsg.2010.11.012

Owen, J. V., Corney, R., Dostal, J., and Vaughan. A. 2010. Significance of "gneissic" rocks in the Liscomb Complex, Nova Scotia; Canadian Journal of Earth Sciences, 47, pp. 927-940. https://doi.org/10.1139/E10-019

Pearce, T. H. 1968. A contribution to the theory of variation diagrams. Contributions to Mineralogy and Petrology,
19, pp. 142-157. https://doi.org/10.1007/BF00635485

Pearce, J. A., Harris, N. B., and Tindle, A.G. 1984. Trace element discrimination diagrams for the tectonic interpretation of granitic rocks. Journal of Petrology, 25, pp. 956-983. https://doi.org/10.1093/petrology/25.4.956

Puchalski, R. 2012. Field relations and petrology of the Trafalgar Plutonic Suite, northern Meguma terrane, Nova Scotia. Unpublished MSc thesis, Acadia University, Wolfville Nova Scotia, 359 p.

Scallion, K. L. 2010. Contamination of plutons by manganiferous country rock in the Governor Lake area, north-central Meguma terrane, Nova Scotia. Unpublished MSc thesis, Dalhousie University, Halifax, Nova Scotia, 312 p.

Scallion, K., Jamieson, R. J., Barr, S. M., White, C. E., and Erdmann, S. 2011. Texture and composition of garnet as a guide to contamination of granitoid plutons, Governor Lake area, Meguma terrane, Nova Scotia. The Canadian Mineralogist, 49, pp. 441-458. https://doi.org/10.3749/ canmin.49.2.441

Stanley, C. 2017. Molar element ratio analysis of lithogeochemical data: a toolbox for use in mineral exploration and mining. In Proceedings of Exploration 17. Sixth Decennial International Conference on Mineral Exploration. Edited by V. Tschirhart and M.D. Thomas, pp. 471-494.

Streckeisen, A. 1976. To each plutonic rock its proper name. Earth-Science Reviews, 12, 1-33. https://doi. org/10.1016/0012-8252(76)90052-0

Sun, S. S. and McDonough, W. F. 1989. Chemical Isotope systematics of the oceanic basalts: implications for mantle composition and processes. In Magmatism in the ocean basins, Edited by A.D. Saunders and M.J. Norry. Geological Society, London, pp. 313-345. https://doi.org/10.1144/ GSL.SP.1989.042.01.19

Tate, M. C. 1995. The relationship between late Devonian mafic intrusions and peraluminous granitoid generation in the Meguma lithotectonic zone, Nova Scotia, Canada. Unpublished PhD thesis, Dalhousie University, Halifax, Nova Scotia, $528 \mathrm{p}$.

Tate, M. C. and Clarke D. B. 1995. Petrogenesis and regional tectonic significance of Late Devonian mafic intrusions in the Meguma Zone, Nova Scotia. Canadian Journal of Earth Sciences, 32, pp. 1883-1898. https://doi. org/10.1139/e95-145

Tate, M.C. and Merrett, D.C. 1994. Compilation of major oxide, trace element, and rare-earth element analyses for Late Devonian peraluminous granitoids in the Meguma Zone, Nova Scotia. Nova Scotia Department of Natural Resources, Open File Report ME 1994-014, 71 p.

van Staal, C.R. 2007. Pre-Carboniferous tectonic evolution and metallogeny of the Canadian Appalachians. In Mineral Resources of Canada: A Synthesis of Major Deposit Types, Distinct Metallogeny, the Evolution of Geological Provinces and Exploration Methods. Edited by W.D. Goodfellow. Geological Association of Canada, Mineral Deposits Division, Special Publication 5, pp. 793-818.

van Staal, C. R., Whalen, J. B., Valverde-Vaquero, P., Zagoreski, A., and Rogers, N. 2009. Pre-Carboniferous, epi- 
sodic accretion-related, orogenesis along the Laurentian margin of the northern Appalachians. Geological Society, London, Special Publications 327, pp. 271-316. https:// doi.org/10.1144/SP327.13

Waldron, J.W.F, Barr, S.M., Park, A.F., White, C.E., and Hibbard, J. P. 2015. Late Paleozoic strike-slip faults in Maritime Canada and their role in the reconfiguration of the northern Appalachian orogen. Tectonics, 34, pp. 1-24. https://doi.org/10.1002/2015TC003882

White, C. E. 2010. Stratigraphy of the Lower Paleozoic Goldenville and Halifax groups in southwestern Nova Scotia. Atlantic Geology, 46, pp. 136-154. https://doi. org/10.4138/atlgeol.2010.008

White, C.E. and Barr, S.M. 2012. The new Meguma: stratigraphy, metamorphism, paleontology, and provenance. Field Trip Guidebook B5, prepared for St. John's 2012 GAC-MAC Joint Annual Meeting, 68 p.

White, C.E. and Scallion, K-L.2011. Bedrock geology map of the Governor Lake area, part of NTS sheets 21E/01, 02,
07, and 08, Colchester, Guysborough, Halifax, and Pictou counties, Nova Scotia. Nova Scotia Department of Natural Resources, Mineral Resources Branch, Open File Map ME 2011-013, scale 1:50 000.

White, C. E., Scallion, K., Barr, S. M., and Jamieson, R. A. 2009a. The Liscomb Complex, Meguma terrane, Nova Scotia: basement or urban legend? Atlantic Geoscience Society Colloquium and General Meeting 2009, Moncton, New Brunswick. Atlantic Geology, 45, pp. 48-49.

White, C. E., Scallion, K., and MacHattie, T. G. 2009b. Geology of the Governor Lake area ('Liscomb Complex'), Parts of NTS Sheets 21E/01, 02, 07 and 08, central Nova Scotia. In Mineral Resources Branch, Report of Activities 2008. Nova Scotia Department of Natural Resources, Report ME 2009-1, pp. 151-165.

Winter, J. D. 2001. An Introduction to Igneous and Metamorphic Petrology, Prentice-Hall Inc., 697 p.

Editorial responsibility: David P. West, Jr. 